\title{
Why Market Returns Favor Democrats in the White House
}

\author{
Michael S Long \\ Faculty of Finance \& Economics, Rutgers Business School, USA
}

Copyright (C) 2015 by authors, all rights reserved. Authors agree that this article remains permanently open access under the terms of the Creative Commons Attribution License 4.0 International License

\begin{abstract}
This study attempts to explain why the equity market earns greater returns for bearing risk when a Democrat is President in the USA versus a Republican. I look at data from 1929 through 2012. The data show that the value weighted return minus the corresponding period's risk free rate is $10.83 \%$ when a Democrat is President, versus a corresponding return of $-1.20 \%$ under Republican Presidents. Two basic macroeconomic arguments exist that should affect market value between the two parties: differences in the risk free interest rates and differences in economic growth. On average the Democrats follow a policy of low interest rates. The rate of return on short-term T-bills averages $4.55 \%$ under the Republicans and a $2.48 \%$ under Democrats. Further, the Democrats overall economic policies create a higher average real growth rate with a $4.8 \%$ average versus only $1.8 \%$ under Republican administrations. Unfortunately, the growth and interest rate differences together do not explain the observed difference in equity market returns. A basic OLS approach with annual value weighted market returns minus the corresponding risk free rate as the dependent variable is run. Neither risk free interest rates nor real economic growth are significant in explaining the observed market returns though the party in power is significant predictor.
\end{abstract}

Keywords Asset Pricing, Market Returns, Political Parties, Market Performance

\section{Why Market Returns Favor Democrats in the White House}

In the United States, two major political parties exist: The Democrats and the Republicans, commonly referred to the GOP (Grand Old Party). The evidence shows that the equity markets perform much better when the Democrats control the White House even though conventional wisdom is that the Republicans are the political party of business. This is not a recent result or a onetime market anomaly, but rather a situation that has existed consistently since Herbert Hoover was President (1929-1933), just after the Center for Research in Security Prices [CRSP] data started. (Figure 1 lists the Presidents from President Hoover through President Obama with their political party.) When the Democrats held the White House, the overall market return premium from holding risky securities (value weighted market returns minus the T-bill rate) was $10.8 \%$ per year versus $-1.2 \%$ with Republican Presidents. The difference in excess returns is a significant $12.03 \%$ /year. Data are also split with the Kennedy administration as he was the first postwar President to pursue economic policies in hopes of affecting real economic outcomes. With this split, the excess market returns on average was $12.78 \%$ versus $-4.36 \%$ in the pre-Kennedy period from Hoover through Eisenhower, and still a large $9.23 \%$ versus $0.16 \%$ in the post-Kennedy period through Obama's first term in 2012. When the Democrats are in the White House, a very large difference is produced in the market returns minus the corresponding risk free rate or the excess return from bearing risk.

\section{Motivation to View Market Return Differences}

Santa-Clara and Valkanov (2003) [21] undertook the most prominent study comparing overall market performance by which party was in power. Their data stopped at the end of 1998. The authors tried about every market test possible to explain their results, but they could find no consistent economic condition to explain the observed results. They obviously believed the market but were very puzzled as to why the widely held views were not observed. Why was the Republicans, being the Party of business, not confirmed as producing a greater market returns than the Democrats?

They considered elections. As most elections are not that close, the market would have a good indication of the winner sometime prior to the election. To get around that problem, they also looked at the four closest races over their sample period. These are obviously the hardest to predict a winner. 
But still they found similar results of no significant surprise returns after the winner is determined. One must remember that their data stopped prior to the Bush-Gore election that took over a month to resolve. ${ }^{1}$

While the market price of bearing risk does vary between the two parties in power, it is impossible to determine exactly why. One consideration is that risk levels vary. In measuring the actual market risk levels, Santa-Clara and Valkanov [21] found that the market volatility is actually higher under Republican presidents. This is contrary to their prior beliefs though the difference was insignificant after controlling for the state of the economy. As a further indication of potential differences in market risk, I consider firm delisting from security markets as a measure of default rates from poor economic activity. No significant differences with various delisting rates are found over the sample period though the delisting rate was slightly higher under a Republican administration.

Santa-Clara and Valkanov [21] also discuss differences in economic policies between the two parties. Again, if this was the cause, the market should react immediately after an election. It is obvious from the market returns observed that no definite pattern exists rather the market seems to react as the presidential term progresses. They did not consider "gridlock" which exists when the party in the White House does not also control the two branches of Congress making it difficult to pass legislation. However, others have viewed this general topic such as Beyer, Jensen, and Johnson (2004) [3], Blinder and Watson (2014) [4], and Diercks and Waller (2014) [6]. They all find that "gridlock" does not affect market returns relative to the party in power.

A final point that Santa-Clara and Valkanov [21] do not discuss in detail is the differences between the value weighted excess returns and those from equal weighted market returns. Over their entire sample period (1927-1998), the Democrats earn $9.01 \%$ greater return with value weighted and a huge $16.52 \%$ with equal weighted. ${ }^{2}$ Viewing just their more recent data of 1963-1998, the differences are even larger. The Democrats produce a higher average return of $6.85 \%$ with value weighted market portfolio and a $17.19 \%$ greater return on average with an equal weighted portfolio. Being conservative in return comparisons, this study only considers the value weighted differences since a few small stocks can drive the equal weighted returns and the objective is to explain the differences in the total market value, which requires a value weighted approach.

The market returns differences, whether they are straight market returns or excess returns from bearing risk, still exist.

1 Snowberg, Wolfers and Zitzewitz (2007) [24] looked at the Bush-Gore election very carefully in viewing election betting systems.

2 Sy and Zaman (2011) [25] explain the size differences as the smaller firms see a greater risk under Democrats than Republicans. However, they never considered differences in the real risk free discount rate. Further they never looked at actual delisting rates between the two parties as discussed above which we found insignificantly higher under Republican Administrations. This would indicate that similar risk premiums should be assumed rather than the higher risk premiums under Democratic administrations, which they indirectly justified.
It is the "cause and effect" that needs to be explained. Beyer, Jensen and Johnson (2004) [3] take a different look in "Don't worry about the election, just watch the Fed." They claim the discount window policy is what drives the return differences as it is what drives the interest rates. Since the President appoints a new, or agrees to keep, the existing Chair of the Federal Reserve Board, it is the President's monetary policies that get carried out. Hence, I focus on the election cycle.

While the equity markets perform better under Democratic administrations versus that of Republican, no real trading rules emerge. The Democrats create about $12 \%$ greater returns per year from bearing risk as market returns minus the time period's corresponding risk free returns. Yet, one still cannot trade on this as the return variances are too large! With our 21 different presidential terms, the Democrat dummy shows significantly higher returns, but explains only $18 \%$ of the overall returns for bearing risk. The greater returns under Democratic administrations could have a random basis. By the time one waits another 84 years to double the sample size, the overall political parties could have totally changed.

After reviewing articles related to this topic, the study starts with replicating and extending the Santa-Clara and Valkanov data from 1998 through 2012. The data shows an even greater advantage for the Democrats as the last two years of the Clinton Presidency gave positive excess returns, as have the first four years of Obama's presidency while the market lost value over the eight years of President George W. Bush.

The objective of this study is to explain these results. The first focus is on differences in the real interest rate between the different political parties in power. With the GOP, the real short term rate averages around $2 \%$. With the Democrats in the White House, the same rate averages $-1 \%$. As they are much different, a simple capital asset pricing model should show a difference in values that would result from a difference in market returns. However, the various risk free interest rates show no significance in explaining market returns.

I next look at the real side of the economy as opposed to the monetary side. The real Gross Domestic Product (GDP) growth rate in the economy averaged $4.8 \%$ under Democrats and only $1.8 \%$ under Republicans from 1929 through 2012. When looking at the growth in earnings for large firms, it averaged $10.14 \%$ under Democratic administrations and a $-0.74 \%$ under the Republicans. Now, this growth difference could result from operating under lower interest rates, but the growth rate is also insignificant in explaining overall market return differences.

The bottom line observed is that the market performs better under Democrat administrations. Lower real short term interest rates and greater real economic growth occur under Democrats, but neither of these are significantly related to the market returns. Hence, the study just ruled out a couple of more apparent arguments. It appears as if the 
results could be just an admiration in market returns similar to the Super Bowl stock predictor model that worked for the first 22 years of the Super Bowl's history (see Krueger and Kennedy, 1990 [13]). Upon expanding the data since then, no predictive power remains. The market now behaves without regard to which league wins the game.

The study continues as follows. A general literature related to the topic is undertaken. The focus moves towards monetary differences and also real growth rate differences. Then the market returns from 1929 through 2012 are compared. A basic model of a firm's returns is summed over all firms to give the total market returns. Both the differences in monetary policy between the two parties that create the different interest rates, and then differences in economic growth rates that give different dividend growth rates are viewed to explain the difference in market returns with some, but not complete success. Finally, conclusions are presented.

\section{General Literature Review}

Unlike most financial economics research that starts with an early article and follows up to the recent articles on the same topic, this review will cover several different, seemingly unrelated topics, except they are related to the premise on why the markets perform better under Democratic administrations.

It starts in reviewing Santa-Clara and Valkanov (2003) [21] following the specific tests that they reported in trying to explain their observed results. They first considered macroeconomic variables related to the business cycle. They wanted to see if the stock market returns were merely a "proxy" for the overall business cycle. They examined the relationship between stock market returns and macro political variables known to forecast the stock market as controls for business market fluctuations. After controlling for the dividend-price ratio, the default and term spreads, and the relative interest rate, they found their results to be even stronger in explaining the observed market return results.

Their next approach looked at "expected" and "unexpected" returns. They found that most of the differences in returns can be attributed to higher "unexpected" returns with the Democrats in power. They note that the market appeared to be systematically positively surprised by the Democrats' policies. These returns might result from the "Fama critique" (Fama, 1998 [7]) applying that the higher returns resulted from a compensation of higher risk being perceived under the Democrats. As a result, any test of rational expectations like the Santa-Clara and Valkanov test was simultaneously a test of rational expectations and of the risk premium.

What about the market returns being a function of the actual election date and returns generated? If the difference was due to a higher ex ante risk premium, one would observe a large movement in stock prices when the uncertainty about which party wins the presidency was resolved. They found no significant evidence of stock price changes immediately before, during or immediately after the elections. The opposite occurred as the difference in returns grew gradually over the term of the presidency.

The second article provided evidence that the markets think the Republicanss will serve the economy better. Snowberg, Wolfers and Zitzewitz (2007) [24] use an event study methodology to view election outcomes. In particular, they studied the 2000 and 2004 elections viewing intra-day movements in the election betting. While interesting, what related directly to this study was the historical stock returns from election-eve close to post-election close. They found electing a Republican president historically gave a 2-3\% boost in the value weighted equity market. This was consistent with folklore of the markets preferring Republicans, but it did not explain why the market failed to stay higher over their administrations.

Next considered are a couple of articles that point out a major problem with this research - lack of independent observations. Elections only occur every 4 years. Some researchers have used dummies to track returns across time. With daily returns, it comes out to about 1000 observations per election cycle. Now, these spurious correlations can give "significant" dummies that actually come from other than political changes. Seasonality and business cycles have similar data problems. Two of these articles are by Ferson, Sarkissian and Simin (2003) [9] and Powell, Shi, Smith and Whaley (2009) [20]. To avoid their potential pitfalls, this study uses a four year window with geometric returns. This greatly reduces the degrees of freedom from around 1,000 for daily returns, considering 250 trading days in a year times a four year term, to one for the election cycle.

\section{Primary Causes for Return Differences}

The focus shifts to what I feel are the major differences in the economy between the two parties creating the market return differences.

\section{A. Monetary Differences}

What is the evidence with interest rates affecting market returns? Substantially, lower real interest rates exist under Democratic administrations. However, most of the literature in this area focuses on monetary policy independent of the party in power. Waud (1970) [27] looked at changes in the discount rate on changes in equity values. He viewed it as resulting from rate changes having a "psychological" effect on the expectations of future economic growth: both greater growth which increases the numerator and a lower discount rate that decreases the denominator. These tend to cause market values to increase though one cannot differentiate which effect is most prevalent.

This leads to Smirlock and Yawitz (1985) [23] who try to 
separate the interest rate changes into; expected rate changes which should have no market reaction; and unexpected changes, which should create an event study type change in value. They find that in the pre-1979 period there was no response to either expected or unexpected rate changes. After 1979, unexpected rate changes produced a systematic market reaction. In a similar paper, Thorbecke (1997) [26] undertook an event study to see how stock return data responded to monetary policy shocks. He found that expansionary policy increases ex-post stock returns. The trouble with these studies is that they focus on immediate market reaction, rather than long term return differences under different monetary policy that this study focuses on.

Continuing with a different approach of monetary policy affecting expected returns, Jensen, Mercer, and Johnson (1996) [11] suggest that the monetary environment influences investors required returns. In an extension to their approach, this study considers the effect on valuation from varying the required returns. These result from different monetary policies. Patelis (1997) [18] goes further in concluding that monetary policy variables are significant predictors of future equity returns though not the only factor to be considered. This allows for differences in economic growth affecting equity valuation also.

Now back to monetary policy, these differences result almost entirely from the actions of the Federal Reserve System. The President gets to appoint the Chairperson of the Federal Reserve Board. They are supposed to carry out monetary policies independent of the President and Congress; however they work at the pleasure of the President. Beyer, Jensen and Johnson (2004) [3] propose watching the FED and not worrying about the election. Their arguments and presentation makes sense, but who is really in charge? I posit that it is the President.

One way to look at this issue is to view Fed Chairs that served under several administrations. Ben Beranke served under both President George W. Bush starting in January 2006 and continued on under President Obama until January 2014. Did his monetary policy change? Under President Bush, the average 3 month T-bill rate was a 3.37\% discount rate in the secondary market during his tenure. The same rate dropped to $0.08 \%$ under President Obama's time in office.

I probably should have stopped, but honesty prevailed. William C. Martin served under President Truman (April, 1951 - January, 1953) with a $1.67 \%$ average, under President Eisenhower (entire two terms) with a $2.31 \%$ average, under Presidents Kennedy and Johnson (entire two terms) with a $3.82 \%$ average, and finally under President Nixon (January 1969-January 1970) with a $6.87 \%$ average. Obviously, an increasing rate pattern emerges in Martin's over twenty years of Chairmanship even as he worked for a Democrat first, then a Republican, back to a pair of Democrats and finally a Republican. The lower average with increasing rates comes from the Democratic administrations coming first.

Finally, Alan Greenspan is considered who was Chairman from August 1987 until the end of January 2006. He served under President Reagan and the first President Bush (August 1987-January 2003) with a $6.20 \%$ average, the entire two terms of President Clinton with a lower $4.75 \%$ average and finally the first five years of President George W. Bush with a continuously falling rate for a $2.13 \%$ average. Again the Democrats are favored with falling rates as the longest term Republican administrations came first. Obviously, the Chairs operated in the momentum of their times which gives the Democrats the lower average risk free rates. The Presidents' policies do not appear to cause the differences, but the results of where Democrats fit in the trends gives them the lower rates and even lower real rates after adjusting for inflation. These three Chairs cover a total of 46 of the 84 year span of our study.

\section{B. Real Economic Growth is Greater under Democratic Administrations}

Finally, what is seen with real economic growth under the two parties? Parker (2006) [17] presents the real GDP growth rates for Democrats and Republicans in the White House from 1929 through 2005. The real growth rate for Democrats averaged $5.1 \%$ and with Republicans only $1.9 \%$ with an overall average value of $3.56 \%$ in his sample period. $\mathrm{He}$ also presented historical values from the 1800's. The more recent overall real average growth rate is in line with the values presented since 1870 . These are real growth rates as inflation was higher under Democrats. Over the sample period of 1929 through 2012, inflation averaged 3.71\% under Democratic administrations and only $2.39 \%$ under the Republicans.

The higher equity value results from the higher economic growth rate that occurs with Democrats versus Republicans. What are those overall growth rates? I started with the Parker study (2006) [17] and extended his average real values to correspond with the market return time period studied. Specifically, the last three years under President George W. Bush are included in the Republican average and the first four years under President Obama are calculated into the Democrats' average. Not surprisingly with the recent poor economic performance, the averages went down slightly. The real economy grew at only a $.47 \%$ rate under President Bush's last three years and not much higher at a $1.63 \%$ rate under President Obama's first term. The average for the Democrats is thus $4.8 \%$ and the Republicans is $1.8 \%$ while the overall rate drops to $3.4 \%$.

As a comparison to show that this is not an anomaly, the corporate earnings growth rate for the S\&P500 is calculated over the same time period. ${ }^{4}$ It is actually negative under the Republicans at $-0.74 \% / \mathrm{yr}$. For Democrats it averages $10.14 \%$. In the Republican's defense, the sample period

3 The only other two Chairs to serve presidents from different parties are Arthur Burns (1970-78) with the last year under President Carter and Paul Volcker (August 1979-August 1987) with the first year and a half under President Carter. The time splits are too short to observe any real trends.

4 These values for dividend yields, dividend growth rates and profits are from Shiller's web site (Online Data Robert Schiller, U.S. Stock Markets 1871-Present and CAPE Rates). The dividends include only traditional dividends without share repurchases. 
includes Herbert Hoover with the Great Depression and then FDR with the economic recovery and WWII. However, even starting with Truman's full term, similar results are obtained. With the real economy growing much more (as well as corporate profits) under Democrats, it should not be a surprise to see the market returns higher under the Democrats. What could be puzzling is why the dividend growth was much closer at $1.96 \%$ for Republicans and $2.46 \%$ for Democrats when the very large differences in the overall economy growth rates were considered.

Blinder and Watson (2014) [4] do explore why the economy varies between the two parties. They focus the real GDP growth rate between the two parties holding the Presidency. They consider the most recent 16 presidential terms from Truman's full term through Obama's first term. They found no indication of a technical explanation such as differential trends or mean reversions. Similarly, no systematic difference in expansionary monetary or fiscal policies appears to exist between the parties. What they attribute the differences to include shocks in oil prices, superior total factor productivity (TFP) performance, the international environment and perhaps more optimistic consumer expectations about the near term future. This sounds almost like data mining or explaining the outcome of an athletic event after it has been played. While they cannot find a solid economic explanation for the growth differences, they do have a good one liner on page 6 of their paper: "Though business votes Republican, it prospers more under Democrats."

\section{Historical Market Return Data}

This section looks at the equity market returns generated under the two USA political parties: Democrats and Republicans. Has one party been able to generate better returns than the other? Specifically, has one party been able to generate greater returns from "bearing risk" or the equity market returns minus the risk free rate? This measures the improvement in wealth from accepting risk over just the straight time value of money.

First, I present the annualized log average returns on value-weighted CRSP stock returns in excess of one-month T-bill yields under each U.S. president in Figure 1. This is an extension of Figure 1 from Santa-Clara and Valkanov (2003) [21]. The dashed line represents the sample average excess returns. One should note that these return differences are even greater when equal weighted market returns are used.

The extension of Figure 1 from the Presidential Puzzle: Political Cycles and the Stock Market by Santa-Clara and Valkanov (2003, JF) [21] where equity returns represent the value weighted market.

The main equity returns data consist of stock returns on all CRSP firms traded on NYSE, AMEX, and NASDAQ. The value-weighted returns is a proxy for returns on large stocks $(L G)$, and the equal-weighted returns is a proxy for returns on small stocks $(S M)$. Hence, they are denoted as LG and SM respectively. For bond returns, Fama maturity bond portfolios returns are obtained from the CRSP U.S. Treasury Database. I have chosen two series of bond returns: first, those with maturity of six to twelve months that are a proxy for returns on Treasury bills, denoted as TNT, and second, those with two to three years maturities that are the proxy for returns on Treasury notes $(T B L)$. Due to the limitations on data availability throughout the sample, I have decided not to use Treasury bond returns over 10 years. Finally, one-month Treasury bill rates $(R F)$ and Consumer Price Index (CPI) growth rates $(I N F)$ are obtained from CRSP to proxy risk-free rates and inflation rates, respectively. All the returns series in lower case are real returns adjusted for inflation, whereas, the returns with the risk-free rates $(R F)$ subtracted are excess returns throughout the paper.

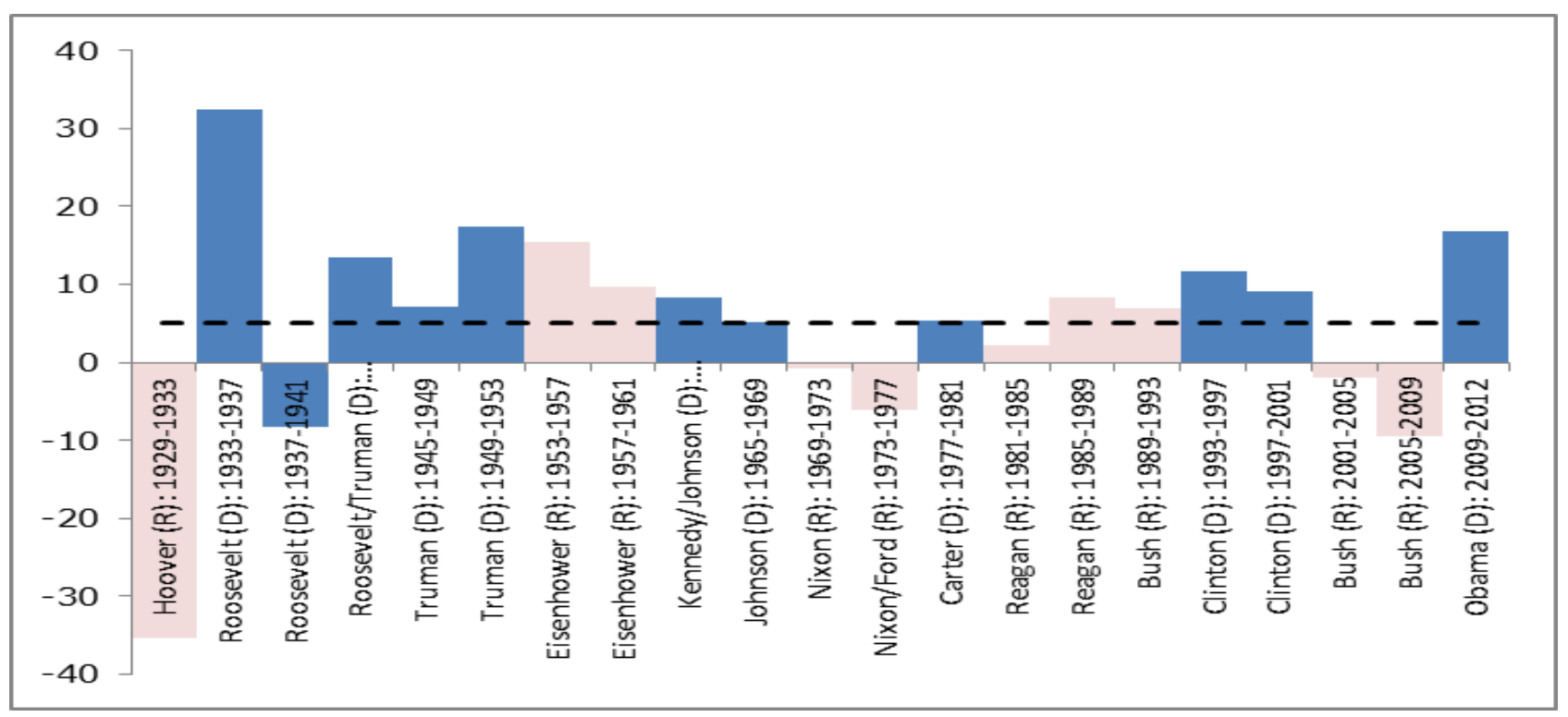

Figure 1. Annual average equity returns in excess of one-month T-bill yields under each U.S. President 
Summary statistics of the data sets are reported in Table 1. All returns are in logarithmic form, annualized, and reported as percentage points. The full sample runs from when Herbert Hoover took office in March 1929 through the end of Barack Obama's first presidential term in December 2012. The full sample is divided into two subsamples with the second sample starting with John F. Kennedy's term (January 1961). The first sub-period is referred to as the pre-Kennedy period and the second sub-period as the post-Kennedy period. Due to data limitations, bond portfolio returns are only reported for the post-Kennedy period.

The table reports the sample average and standard deviation of all returns series. The full sample period runs from 1929:04-2012:12 for all returns series, except for Treasury returns series, for which the data goes back to 1951:01. The pre-Kennedy subsample period ends in 1960:12, whereas the post-Kennedy subsample period starts in 1961:01. Treasury returns series are unreported for the pre-Kennedy sample period due to lack of sufficient data. $\mathrm{SM}(\mathrm{LG})$ is the equal (value) -weighted returns on all CRSP firms traded on NYSE, AMEX, and NASDAQ, as a proxy for returns on small (large) stocks. TNT (TBL) is the equal-weighted Fama maturity portfolio returns with maturity over 2 years and less than 3 years (over 6 months and less than 12 months), as a proxy for returns on Treasury notes (bills). RF is the one-month Treasury bill rates. INF is the growth rate of the Consumer Price Index. All returns series are obtained from CRSP. Nominal returns are reported under Panel A. Lower-cased returns are real returns adjusted for inflation in Panel B, while returns subtracted from RF are excess returns over risk-free rates in Panel C. All returns are reported as percentage points of annualized cumulative returns.

Baily (1978) [1] notes that while all modern Presidents had intervened in the economy, John F. Kennedy was the first one to do so overtly and systematically to control the overall economy. This is why the full sample period is divided into pre- and post-Kennedy periods. If there were to be any systematic differences in economic policies between two political parties, one would expect to observe a more striking difference in the post-Kennedy period, which is documented in Table 2. The differences in annualized average stock returns are economically more significant and larger during the pre-Kennedy period, ranging from $17.14 \%$ (excess returns on large stocks) to $24.53 \%$ (excess returns on small stocks), whereas, in the post-Kennedy period, the differences range from $9.23 \%$ (excess returns large stocks) to $14.54 \%$ (excess returns on small stocks). The statistical significances, however, are all higher in the post-Kennedy period. This finding seems to suggest that a structural break in economic policies set by presidents is related to the apparent differences in stock returns under different political parties and that the Democratic risk premium that Santa-Clara and Valkanov (2003) [21] documented is not very likely to be the result of a statistical fluke. These have motivated me to try to better understand this presidential puzzle in a simple analytical framework.

Table 1. Summary Statistics of Interest Rates

\begin{tabular}{|c|c|c|c|c|c|c|}
\hline \multirow[b]{2}{*}{ Series } & \multicolumn{2}{|c|}{ Full sample } & \multicolumn{2}{|c|}{ Pre-Kennedy sample } & \multicolumn{2}{|c|}{ Post-Kennedy sample } \\
\hline & Average & Std. Dev. & Average & Std. Dev. & Average & Std. Dev. \\
\hline \multicolumn{7}{|c|}{ Panel A: Nominal Returns } \\
\hline$S M$ & 11.57 & 24.86 & 10.87 & 31.41 & 12.00 & 19.85 \\
\hline$L G$ & 8.57 & 18.98 & 7.39 & 23.39 & 9.29 & 15.69 \\
\hline$T N T$ & 5.84 & 3.26 & & & 6.34 & 3.42 \\
\hline$T B L$ & 5.24 & 1.47 & & & 5.68 & 1.53 \\
\hline$R F$ & 3.47 & 0.90 & 1.07 & 0.33 & 4.94 & 0.87 \\
\hline$I N F$ & 3.10 & 1.85 & 1.74 & 2.50 & 3.93 & 1.24 \\
\hline \multicolumn{7}{|c|}{ Panel B: Real Returns } \\
\hline$s m$ & 8.47 & 24.88 & 9.12 & 31.33 & 8.07 & 19.95 \\
\hline $\lg$ & 5.47 & 19.02 & 5.64 & 23.32 & 5.36 & 15.84 \\
\hline tnt & 2.30 & 3.48 & & & 2.41 & 3.66 \\
\hline$t b l$ & 1.70 & 1.72 & & & 1.75 & 1.80 \\
\hline$r f$ & 0.37 & 1.82 & -0.68 & 2.55 & 1.01 & 1.15 \\
\hline \multicolumn{7}{|c|}{ Panel C: Excess Returns } \\
\hline$S M-R F$ & 8.10 & 24.92 & 9.80 & 31.45 & 7.05 & 19.92 \\
\hline$L G-R F$ & 5.09 & 19.02 & 6.32 & 23.42 & 4.34 & 15.74 \\
\hline$T N T-R F$ & 1.33 & 3.14 & & & 1.40 & 3.30 \\
\hline$T B L-R F$ & 0.73 & 1.15 & & & 0.74 & 1.22 \\
\hline
\end{tabular}


Table 2. Average Returns under Democratic and Republican Presidents

\begin{tabular}{|c|c|c|c|c|c|c|c|c|c|}
\hline \multirow[b]{2}{*}{ Series } & \multicolumn{3}{|c|}{ Full sample } & \multicolumn{3}{|c|}{ Pre-Kennedy sample } & \multicolumn{3}{|c|}{ Post-Kennedy sample } \\
\hline & Dem & Rep & Diff & Dem & Rep & Diff & Dem & Rep & Diff \\
\hline \multicolumn{10}{|c|}{ Panel A: Nominal Returns } \\
\hline \multirow[t]{2}{*}{$S M$} & 19.06 & 3.35 & 15.71 & 19.53 & -3.45 & 22.98 & 18.68 & 6.27 & 12.41 \\
\hline & $(0.00)$ & $(0.45)$ & $(0.01)$ & $(0.01)$ & $(0.71)$ & $(0.07)$ & $(0.00)$ & $(0.19)$ & $(0.04)$ \\
\hline \multirow[t]{2}{*}{$L G$} & 13.32 & 3.36 & 9.96 & 13.26 & -2.32 & 15.59 & 13.36 & 5.79 & 7.57 \\
\hline & $(0.00)$ & $(0.33)$ & $(0.03)$ & $(0.01)$ & $(0.79)$ & $(0.12)$ & $(0.00)$ & $(0.08)$ & $(0.09)$ \\
\hline \multirow[t]{2}{*}{$T N T$} & 4.12 & 7.03 & -2.91 & & & & 4.21 & 8.17 & -3.95 \\
\hline & $(0.00)$ & $(0.00)$ & $(0.00)$ & & & & $(0.00)$ & $(0.00)$ & $(0.00)$ \\
\hline \multirow[t]{2}{*}{$T B L$} & 4.18 & 5.97 & -1.79 & & & & 4.28 & 6.88 & -2.60 \\
\hline & $(0.00)$ & $(0.00)$ & $(0.04)$ & & & & $(0.00)$ & $(0.00)$ & $(0.00)$ \\
\hline \multirow[t]{2}{*}{$R F$} & 2.48 & 4.55 & -2.07 & 0.48 & 2.04 & -1.55 & 4.14 & 5.63 & -1.49 \\
\hline & $(0.00)$ & $(0.00)$ & $(0.01)$ & $(0.00)$ & $(0.00)$ & $(0.00)$ & $(0.00)$ & $(0.00)$ & $(0.09)$ \\
\hline \multirow[t]{2}{*}{$I N F$} & 3.66 & 2.48 & 1.18 & 3.75 & -1.56 & 5.31 & 3.59 & 4.22 & -0.63 \\
\hline & $(0.00)$ & $(0.00)$ & $(0.26)$ & $(0.00)$ & $(0.28)$ & $(0.00)$ & $(0.00)$ & $(0.00)$ & $(0.46)$ \\
\hline \multicolumn{10}{|c|}{ Panel B: Real Returns } \\
\hline \multirow[t]{2}{*}{$s m$} & 15.40 & 0.87 & 14.54 & 15.78 & -1.88 & 17.67 & 15.09 & 2.05 & 13.04 \\
\hline & $(0.00)$ & $(0.84)$ & $(0.02)$ & $(0.05)$ & $(0.83)$ & $(0.15)$ & $(0.00)$ & $(0.67)$ & $(0.04)$ \\
\hline \multirow[t]{2}{*}{$\lg$} & 9.66 & 0.87 & 8.78 & 9.52 & -0.76 & 10.28 & 9.78 & 1.57 & 8.20 \\
\hline & $(0.00)$ & $(0.80)$ & $(0.05)$ & $(0.05)$ & $(0.93)$ & $(0.29)$ & $(0.00)$ & $(0.64)$ & $(0.07)$ \\
\hline \multirow[t]{2}{*}{ tnt } & 0.65 & 3.45 & -2.80 & & & & 0.63 & 3.95 & -3.32 \\
\hline & $(0.34)$ & $(0.00)$ & $(0.01)$ & & & & $(0.37)$ & $(0.00)$ & $(0.01)$ \\
\hline \multirow[t]{2}{*}{$t b l$} & 0.71 & 2.39 & -1.68 & & & & 0.69 & 2.66 & -1.97 \\
\hline & $(0.16)$ & $(0.00)$ & $(0.03)$ & & & & $(0.18)$ & $(0.00)$ & $(0.02)$ \\
\hline \multirow[t]{2}{*}{$r f$} & -1.18 & 2.07 & -3.25 & -3.26 & 3.60 & -6.86 & 0.55 & 1.41 & -0.86 \\
\hline & $(0.09)$ & $(0.00)$ & $(0.00)$ & $(0.00)$ & $(0.01)$ & $(0.00)$ & $(0.22)$ & $(0.01)$ & $(0.22)$ \\
\hline \multicolumn{10}{|c|}{ Panel C: Excess Returns } \\
\hline \multirow[t]{2}{*}{$S M-R F$} & 16.58 & -1.20 & 17.78 & 19.05 & -5.49 & 24.53 & 14.54 & 0.64 & 13.91 \\
\hline & $(0.00)$ & $(0.79)$ & $(0.00)$ & $(0.02)$ & $(0.56)$ & $(0.05)$ & $(0.00)$ & $(0.90)$ & $(0.03)$ \\
\hline \multirow[t]{2}{*}{$L G-R F$} & 10.83 & -1.20 & 12.03 & 12.78 & -4.36 & 17.14 & 9.23 & 0.16 & 9.07 \\
\hline & $(0.00)$ & $(0.73)$ & $(0.01)$ & $(0.01)$ & $(0.61)$ & $(0.09)$ & $(0.00)$ & $(0.96)$ & $(0.04)$ \\
\hline \multirow[t]{2}{*}{$T N T-R F$} & 0.08 & 2.20 & -2.11 & & & & 0.08 & 2.53 & -2.46 \\
\hline & $(0.90)$ & $(0.00)$ & $(0.01)$ & & & & $(0.90)$ & $(0.00)$ & $(0.01)$ \\
\hline \multirow[t]{2}{*}{$T B L-R F$} & 0.15 & 1.14 & -0.99 & & & & 0.14 & 1.25 & -1.11 \\
\hline & $(0.55)$ & $(0.00)$ & $(0.00)$ & & & & $(0.58)$ & $(0.00)$ & $(0.00)$ \\
\hline
\end{tabular}

The table reports the sample average returns under Democratic (Dem) presidents and Republican (Rep) presidents and the average return difference (Diff). The p-values reported below the coefficients on Dem and Rep are obtained under the null that returns are zero, whereas the p-values reported below the average return differences are obtained under the null of no return difference. All standard errors are corrected for heteroskedacity and autocorrelation following Newey and West (1987, 1994) [15][16]. Whenever the null of no return difference can be rejected at the usual significance level, the coefficients are bold-faced.

Estimates of expected returns use dividend growth model, earnings growth model, and historical sample average. All returns are in percent and p-values under the null of no difference are in parentheses. The standard errors are corrected using Newey-West covariance matrix. 
Table 3. Estimates of Expected Real Returns under Democratic and Republican Presidents

\begin{tabular}{|c|c|c|c|}
\hline Series & Republican & Democratic & Difference \\
\hline \multicolumn{4}{|l|}{ Panel A: Growth rates } \\
\hline \multirow[t]{2}{*}{ Inflation } & 2.39 & 3.71 & 1.33 \\
\hline & & & $(0.21)$ \\
\hline \multirow[t]{2}{*}{ Dividend yield (1) } & 3.83 & 4.32 & 0.49 \\
\hline & & & $(0.37)$ \\
\hline \multirow[t]{2}{*}{ Dividend growth (2) } & 1.96 & 2.46 & 0.50 \\
\hline & & & $(0.75)$ \\
\hline \multirow[t]{2}{*}{ Earnings growth (3) } & -0.74 & 10.14 & 10.89 \\
\hline & & & $(0.05)$ \\
\hline \multirow[t]{2}{*}{ Capital gains yield (4) } & 2.27 & 6.64 & 4.36 \\
\hline & & & $(0.31)$ \\
\hline \multicolumn{4}{|l|}{ Panel B: Average returns } \\
\hline \multirow[t]{2}{*}{$(1)+(2)$} & 5.79 & 6.78 & 0.99 \\
\hline & & & $(0.56)$ \\
\hline \multirow[t]{2}{*}{$(1)+(3)$} & 3.08 & 14.50 & 11.42 \\
\hline & & & $(0.04)$ \\
\hline \multirow[t]{2}{*}{$(1)+(4)$} & 6.10 & 10.95 & 4.85 \\
\hline & & & $(0.26)$ \\
\hline
\end{tabular}

Using the historical sample,

$$
R_{t}=\frac{D_{t}}{P_{t-1}}+\frac{P_{t}-P_{t-1}}{P_{t-2}}
$$

Using the Gordon's dividend growth model (Gordon, 1959) [10],

$$
R_{t}=\frac{D_{t}}{P_{t-2}}+G_{t}
$$

Then, we have to estimate $G_{t}$ using either dividend growth or earnings growth.

Note from the data that most presidents seem to be consistent is in producing greater returns in the third and fourth years of their terms as they get ready for the next election. In "Washington meets Wall Street: A closer examination of the presidential cycle puzzle," Kraussl et al ( 2014) [12] found that the annual excess returns of the S\&P500 were almost $10 \%$ higher during the last two years of a president's four year term. Many economic explanations were tried with little effect. They concluded that the presidential cycle effect in U.S. financial markets remains a puzzle.

\section{Firm Valuation and Required Returns}

I consider differences in returns that result from the differences in the dividend yields and the growth in dividends between the two parties being in power. This is based on the basic concept of firm valuation from Miller and Modigliani's dividend article (Miller and Modigliani, 1962)
[14]. They initially presented the valuation process in explaining dividend payout irrelevance. They noted that the return on an equity security was the sum of its dividend yield and the capital gain from future growth in dividends. Now, using a constant growth across time as a simplifying assumption, the value for security $\mathrm{j}$ is

$$
\mathrm{V}_{\mathrm{j}}=\mathrm{D}_{1 \mathrm{j}} /\left(\mathrm{K}_{\mathrm{j}}-\mathrm{G}_{\mathrm{j}}\right)
$$

Where $\mathrm{K}_{\mathrm{j}}$ is its required return, $\mathrm{G}_{\mathrm{j}}$ is the growth rate and $D_{1 j}$ is the dividend at time 1 . This can be expressed in terms of the required return as

$$
\mathrm{K}_{\mathrm{j}}=\mathrm{D}_{1 \mathrm{j}} / \mathrm{V}_{\mathrm{j}}+\mathrm{G}_{\mathrm{j}}
$$

The required return can also be expressed using the Capital Asset Pricing Model (Sharpe, 1964) [22]. The required return, $K_{j}$, is equal to the risk free rate $\left(R_{f}\right)$ plus the market price of risk $\left(\mathrm{RP}_{\mathrm{M}}\right)$. Or for a single firm $\mathrm{j}$, it is the market risk premium $\left(\mathrm{RP}_{\mathrm{M}}\right)$ multiplied by firm $\mathrm{j}$ 's beta value (its relative systematic risk) plus the risk free rate to give the required return.

$$
\mathrm{K}_{\mathrm{j}}=\mathrm{R}_{\mathrm{f}}+\mathrm{RP}_{\mathrm{M}} \times \mathrm{B}_{\mathrm{j}}
$$

The goal is to explain how total market returns change from varying the Party in the White House. This requires an understanding of the total market value, which is determined from the value weighted sum of all the firms.

$$
\begin{aligned}
& \mathbf{V}_{\mathbf{M}}=\Sigma \mathrm{w}_{\mathrm{j}} \mathrm{V}_{\mathrm{j}} \\
& \text { Where } \Sigma \mathrm{w}_{\mathrm{j}}=1.0
\end{aligned}
$$

As the value weighted or average beta is equal to 1.0 by definition, 


$$
\mathbf{V}_{\mathbf{M}}=\mathbf{D}_{\mathbf{M}} /\left(\mathrm{R}_{\mathrm{f}}+\mathrm{RP}_{\mathrm{M}}-\mathbf{G}_{\mathbf{M}}\right)
$$

Where $\mathbf{D}_{\mathbf{M}}$ is the total dividends paid and $\mathbf{G}_{\mathbf{M}}$ is the growth rate of the overall market. The only other variables in determining the overall market level are the risk free rate and the market risk premium. As the market risk premium cannot be directly measured, it is assumed as constant across time and parties in power. As a measure of economic risk, I also looked at the delisting rate from the NYSE. It is insignificantly higher with the Republican administrations in the White House.

The market risk premium is $5.09 \%$. This is determined as the real return premium calculated using geometric returns. This seems and is much lower than risk premiums usually used. As a typical risk premium, it is compared with Brealey, Myers and Allen (2006) [5] values. They reported an expected return on S\&P500 through 2003 with an average of $11.7 \%$ in nominal terms $(8.5 \%$ real return $)$ while the average short term T-bill rate was 3.8\% (0.7\% real). This results in an $8 \%$ risk premium. This is almost twice the $5.09 \%$ value from using geometric returns instead of their (and other commonly reported values) simple average or arithmetic returns. The following analysis was also worked with their larger risk premium and similar results are obtained.

In comparing the difference in market returns between the two political parties being in power, the focus is on two simple variables that were presented earlier. The parties differ in their average risk free rate which results from the government's monetary policy. And parties differ in the dividend growth rate that results from the government's economic policy and subsequent economic growth rate.

\section{Explaining the Market Return Differences}

The differences in the observed market returns between the political parties in power are considered first with a valuation model and then are tested directly with the observed data.

\section{A. Valuation Model}

The differences in required returns and dividend growth can explain the market return differences between the two parties in power. This difference results from the substantially lower risk free rate during Democratic Administrations versus the average rate under Republican Presidents and a substantially higher dividend growth rate under Democratic Administrations. In the previous section, the firm's value was shown to be a function of its dividends,

5 I ran the delisting rate as the number of firms delisted from the total number of NYSE firms using three ratios. First, all firms delisted found slightly more firms delisted under Republican administrations. As the largest portion of firms delisted was for mergers, I dropped those firms for our second ratio finding similar results. Finally, the third ratio considered only firms delisted because of liquidation or dropped from the exchanges. The delisting ratio is still slightly greater under the Republicans. I considered only NYSE firms as the data on ASEX started only in 1962 and NASDAQ did not start until 1972. dividends growth and the required return on these dividends or using the simple constant growth model in equation 5), $\mathbf{V}$ $=\mathbf{D}_{\mathrm{M}} /\left(\mathrm{K}-\mathbf{G}_{\mathbf{M}}\right)$. The overall average market return is now given in equation 6)

$$
\mathrm{R}_{\mathrm{A}}=\left(\mathrm{V}_{1}-\mathrm{V}_{0}+\mathrm{D}_{\mathrm{M}}\right) / \mathrm{V}_{0}
$$

Now, considering everything else constant for the average over the sample period, the $\mathrm{V}$ values are $\mathrm{V}_{0}=\mathrm{D}_{\mathrm{M}} /(0.0347+$ $0.0509-0.0222)$ and $\mathrm{V}_{1}=1.0222 \times \mathrm{D}_{\mathrm{M}} /(0.0347+0.0509-$ $0.0222)$. For,

$$
\begin{aligned}
\mathrm{R}_{\mathrm{A}} & =1.0222 \times \mathrm{D}_{\mathrm{M}}-\mathrm{D}_{\mathrm{M}}+\mathrm{D}_{\mathrm{M}} \times(0.0347+0.0509-0.0222) \\
& =0.0856
\end{aligned}
$$

While this is a rather roundabout way to calculate the required return, it will show that the return varies on average between the Democrats and Republicans being in power. Now if the Democrats averaging of a $2.48 \%$ risk free rate and a $2.46 \%$ dividend growth rate were to come into power and stay, the resulting return moving from our initial average risk free rate and growth rate would be

$$
\begin{aligned}
\mathrm{R}_{\mathrm{D}} & =\left[1.0246 \times \mathrm{D}_{\mathrm{M}} /(0.0248+0.0509-0.0246)-\mathrm{D}_{\mathrm{M}} /(0.0347\right. \\
& \left.+0.0509-0.0222)+\mathrm{D}_{\mathrm{M}}\right] / \mathrm{D}_{\mathrm{M}} /(0.0347+0.0509-0.0222) \\
& =0.3346
\end{aligned}
$$

On the other side, the Republican average values of $4.55 \%$ risk free rate and $1.96 \%$ dividend grow rate would give the following return

$$
\begin{aligned}
& \mathrm{R}_{\mathrm{R}}=\left[1.0196 \times \mathrm{D}_{\mathrm{M}} /(0.0455+0.0509-0.0196)-\mathrm{D}_{\mathrm{M}} /(0.0347\right. \\
& \left.+0.0509-0.0222)+\mathrm{D}_{\mathrm{M}}\right] / \mathrm{D}_{\mathrm{M}} /(0.0347+0.0509-0.0222) \\
& =-0.0949
\end{aligned}
$$

These values require a rather naïve view of the securities markets and the political system in general. These perpetual models assume that once a party obtains power, it continuously stays in power. Obviously this is not very realistic in the USA where the 84 years or 21 presidential terms studied finds 11 Democratic terms and 10 Republican terms - almost even.

Instead, assume that the markets adjust to the party's average values for the next four years and then revert to the long term average values. This gives

$$
\begin{gathered}
\mathrm{V}_{\mathrm{R}}=\mathrm{D}_{\mathrm{M}}(1.0196) / 1.0964+\mathrm{D}_{\mathrm{M}}(1.0196)^{2} / 1.0964^{2}+ \\
\mathrm{D}_{\mathrm{M}}(1.0196)^{3} / 1.0964^{3}+\mathrm{D}_{\mathrm{M}}(1.0196)^{4} / 1.0964^{4}+ \\
{\left[\mathrm{D}_{\mathrm{M}}(1.0196)^{4} /(0.0856-0.0222)\right] /(1.0964)^{4}=15.144 \mathrm{D}_{\mathrm{M}}}
\end{gathered}
$$

for Republicans. For Democrats it is

$$
\begin{gathered}
\mathrm{V}_{\mathrm{D}}=\mathrm{D}_{\mathrm{M}}(1.0246) / 1.0757+\mathrm{D}_{\mathrm{M}}(1.0246)^{2} / 1.0757^{2}+ \\
\mathrm{D}_{\mathrm{M}}(1.0246)^{3} / 1.0757^{3}+\mathrm{D}_{\mathrm{M}}(1.0246)^{4} / 1.0757^{4}+ \\
{\left[\mathrm{D}_{\mathrm{M}}(1.0246)^{4} /(0.0856-0.0222)\right] /(1.0757)^{4}=16.529 \mathrm{D}_{\mathrm{M}}}
\end{gathered}
$$

The market returns for each party over the average return can now be calculated as done earlier with the new values for just four years in power replacing the perpetual values. This gives for Democrats a return of

$$
\begin{gathered}
R_{D}=\left[16.529-D_{M} /(0.0347+0.0509-0.0222)+\right. \\
\left.D_{M}\right] / D_{M} /(0.0347+0.0509-0.0222)=0.1113
\end{gathered}
$$

On the other side, the Republican average values of $4.55 \%$ 
risk free rate and $1.96 \%$ dividend growth rate would give the following return

$$
\begin{gathered}
R_{R}=\left[15.144-D_{M} /(0.0347+0.0509-0.0222)+D_{M}\right] / \\
D_{M} /(0.0347+0.0509-0.0222)=0.0235
\end{gathered}
$$

These are much closer. Now the initial return comparison gave the real return from bearing risk for the two parties, or the average return minus the real risk free rate. To obtain those values from a growth model, the average real risk free rates are now subtracted. The rates are $2.07 \%$ for GOP and a $-1.18 \%$ for Democrats. The net values become

$$
\mathrm{R}_{\mathrm{D}}=0.1113-(-0.0118)=0.1231
$$

for the Democrats, and

$$
\mathrm{R}_{\mathrm{R}}=0.0235-0.0207=0.0028
$$

for the Republicans. The difference between the two parties sees the Democrats being favored by

$$
\mathrm{R}_{\mathrm{D}}-\mathrm{R}_{\mathrm{R}}=0.1231-0.0028=0.1203 \text { or } 12.03 \%
$$

The actual values calculated found the Democrats producing a $10.8 \%$ excess return over the risk free rate, and the GOP showing a comparable return of a $-1.2 \%$. While the growth model values are slightly higher, the difference is still $12 \%$.

\section{B. Direct Empirical Tests to Explain Market Return Differences}

Does the idea of differences in real risk free interest rates and growth rates actually hold with security market valuations? The short answer is, no. To see this, one must look at what is significantly related to annual market returns. ${ }^{6}$ A simple OLS regression is run. First, the party in power is considered as a dummy variable. It significantly predicts market returns with the Democrats showing higher returns. The idea is to add the risk free rate and various growth rates as independent variables. Ideally, the risk free interest rate and/or the real economic growth rates would be significant predictors of the market returns and the party in power would become insignificant. This would provide positive evidence consistent with the model.

Unfortunately, neither risk free interest rates nor the various growth rates are significantly related to overall market returns. With a dependent variable being the value weighted excess returns (the market weighted index minus the corresponding risk free rate), the Democrats in power dummy variable is statistically significant. Now, the simple model explains the greater returns from the greater economic growth rates from Democrats and the lower interest rates that they operate under. However, even after trying various approaches to risk free rates (risk free rate, real risk free rate,

6 The annual is by calendar year. Currently, the US President takes office on January 20 in the year following the election. The calendar year closely matches the time in office. However, initially in USA, the power changed on March 4. Roosevelt's first inauguration was the last at the original date. Hence our data has Hoover picking up the last two months of Coolidge's Presidency where they were both Republicans. It also has Roosevelt picking up the last two months of Hoover's Presidency where Roosevelt was a Democrat. lagged one year rate) and similarly with growth rates (annual growth rate, rate lagged one year, and change in growth rate from previous year), none are significant and at best they just made the dummy for Democrats in power insignificant. This makes one think that the results could be similar to now debunked Super Bowl market predictor. That with enough elections, the market return differences between the two parties in the White House will become insignificant even though under the Democrats the risk free interest rate is lower and the real economic growth rate is higher.

What is the Super Bowl market predictor? It was observed that after a team in the original National Football League (NFL), basically the current National Football Conference (NFC) plus the original Cleveland, Pittsburgh and Baltimore franchises, won the Super Bowl that the Stock Market showed positive returns the year of the game. When an American Football League (AFL), now American Football Conference (AFC), team won, the market posted negative returns. Krueger and Kennedy (1990) [13] published this idea showing that the S\&P 500 gained on average $15.2 \%$ after an NFL win and lost $10.9 \%$ after an AFL win looking at the first 22 games. (The sample size is almost identical to the 21 elections.) Their bull and bear results held in 20 of the first 22 Super Bowls.

Does this type of anomaly hold over the long run indicating a real factor in market returns, or is it an adoration that future observations with a larger sample size will correct? I collected the next 24 wins through the 2013 season $^{7}$ and corresponding S\&P returns. Both conferences now show positive returns with the NFC average of $11.77 \%$ and the AFC average of $8.66 \%$ and both have the same percentage of negative years with 4 out of 19 for NFC and 1 out of 5 for the AFC. One could expect this is what is driving the greater market returns under Democratic administrations. It is only a market aberration that time will average out like the Super Bowl Market Predictor. Unfortunately, with an election only every four years, it will take another 96 years to complete our sample for a future comparison!

\section{Conclusions}

This study starts by showing that the market earns excess returns when a Democrat is president in the USA. The data extends the early Santa-Clara and Valkanov paper [21] though 2012. The extended results are even more favorable for the Democrats.

The main contribution of the study, however, is an attempt to explain the market anomaly. It uses two basic macroeconomic arguments: monetary policy and fiscal policy. On average the Democrats operated under lower interest rates. The real rate of return on T-bills averages $2 \%$ with the Republicans in the White House and a $-1 \%$ under Democrats. Using a valuation model, this should explain

7 While 2014 had not closed when data was collected, the Seattle win creates a problem. It was an expansion franchise after the Super Bowl had started and was originally in the AFC. Later during a divisional realignment it was moved the NFC making its classification undetermined. 
about half of the return differences. The Democrats also saw higher dividend growth rates when in office from their administration creating higher average real growth rate with a $4.8 \%$ average versus only $1.8 \%$ under Republican administrations. However, the interest rates and growth values are not significantly related to the market returns when viewing the actual annual returns. One must remember that the equity markets are forward looking to future dividends. What drives these returns cannot be easily explained. It could be similar to the "Super Bowl Stock Predictor" that looked really good for the first 22 years of the Super Bowl, but has totally become unrelated to the Super Bowl winner in viewing the next 24 years. However, lower interest rates and a higher economic growth appear to present a much better economic rationale for higher market returns than old city franchises versus new city franchises with the Super Bowl story for market returns.

\section{Acknowledgements}

I would like to thank Ileen Malitz for suggesting that I update the empirical work comparing the market returns and the party in power. I would also like to thank Sang Hyun (Hugh) Kim for his research support and empirical suggestions. I am responsible for any errors, omissions, etc.

\section{REFERENCES}

[1] Baily M. Stabilization Policy and Private Economic Behavior. Brookings Papers on Economic Activity. 1978; 1:1- 50.

[2] Bartels L. Unequal Democracy: The Political Economy of the New Gilded Age. Princeton NJ: Princeton University Press; 2008.

[3] Beyer S, Jensen G, Johnson R. Don't Worry about Elections, Just Watch the Fed. Journal of Portfolio Management. 2004; 30 (4): 101-109.

[4] Blinder A, Watson M Presidents and the U.S. economy: An Econometric Exploration. National Bureau of Economic Research Working Paper. 2014; w20324.

[5] Brealey R, Myers S, Allen F. Principles of Corporate Finance, $8^{\text {th }}$ Ed., New York: M $^{\mathrm{c}}$ Graw-Hill Irwin; 2006.

[6] Diercks A, Waller W. Taxes, Spending and Market Returns. Department of Economics The University of North CarolinaChapel Hill Working Paper. 2014.

[7] Fama, E. Market Efficiency, Long-term Returns, and Behavioral Finance. 1998; 49(3): 283-306.

[8] Fama E, French K. The Equity Premium. The Journal of Finance. 2002; LXII (2); 637-659.

[9] Ferson W, Sarkissian S, Simin T. Spurious Regressions in Financial Economics? The Journal of Finance. 2003; LVIII
(4): 1393-1413.

[10] Gordon, M. Dividends, Earnings and Stock Prices. Review of Economics and Statistics. 1959; 41 (2): 99-105.

[11] Jensen G, Mercer J, Johnson R. Business Conditions, Monetary Policy, and Expected Security Returns. Journal of Financial Economics. 1996; 40: 213-237.

[12] Kraussl R, Lucas A, Rijbergen D, van der Sluis P, Vrugt E. Washington Meets Wall Street: A Closer Examination of Presidential Cycle Puzzle. Journal of International Money and Finance. 2014; 43: 50-69.

[13] Krueger T, Kennedy W. An Examination of the Super Bowl Stock Predictor Model. The Journal of Finance. 1990; XLV (2): 691-697.

[14] Miller M, Modigliani F. Dividend Policy, Growth and the Valuation of Shares. Journal of Business. 1962; 34: 411-433.

[15] Newey W, West K. A Simple, Positive Semi-definite, Heteroskedasticity and Autocorrelation Consistent Covariance Matrix. Econometrica. 1987; 55 (3): 703-708.

[16] Newey W, West K. Automatic Lag Selection in Covariance Matrix Estimation. Review of Economic Studies. 1994; 61 (4): 631-654.

[17] Parker E. Does the Party in Power Matter for Economic Performance? Economic Working Paper, University of Nevada, Reno. 2006.

[18] Patelis A. Stock Returns Predictability and the Role of Monetary Policy. The Journal of Finance. 1997; LII (5): 1951-1972.

[19] Peace D, Roley V., 1985, "Stock Prices and Economic News," Journal of Business. 1985; 58 (1): 49-67.

[20] Powell J, Shi J, Smith T, Whaley R. Political Regimes, Business Cycles, Seasonalities, and Returns. Journal of Banking and Finance. 2009; 33: 1112-1128.

[21] Santa-Clara P, Valkanov R. The Presidential Puzzle: Political Cycles and the Stock Market. The Journal of Finance. 2003; LXIII (5): 1841-1872.

[22] Sharpe W. Capital Asset Prices: A Theory of Market Equilibrium under Conditions of Risk. The Journal of Finance. 1964; XXIV (4): 425-442.

[23] Smirlock M, Yawitz J. Asset Returns, Discount Rate Changes, and Market Efficiency. The Journal of Finance. 1985; XL (4): 1141-1158.

[24] Snowberg E, Wolfers J, Zitzewitz E. Partisan Impacts on the Economy: Evidence from Prediction Markets and Close Elections. The Quarterly Journal of Economics. 2007; CXXII: 807-829.

[25] Sy O, Al Zaman A. Resolving the Presidential Puzzle. Financial Management. 2011; (Summer): 331-355.

[26] Thorbecke W. On Stock Market Returns and Monetary Policy. The Journal of Finance. 1997; LII (2): 636-654.

[27] Waud R. Public Interpretation of Federal Reserve Discount Rate Changes: Evidence on the "Announcement Effect." Econometrica 1970; 38 (2): 231-250. 